Georgetown University Law Center

Scholarship @ GEORGETOWN LAW

2009

\title{
Global Governance: The World Trade Organization's Contribution
}

Andrew D. Mitchell

Georgetown University Law Center, a.mitchell@unimelb.edu.au

Elizabeth Sheargold

University of Melbourne Law School

This paper can be downloaded free of charge from:

https://scholarship.law.georgetown.edu/facpub/386

46 Alta. L. Rev. 1061-1080 (2008-2009)

This open-access article is brought to you by the Georgetown Law Library. Posted with permission of the author. Follow this and additional works at: https://scholarship.law.georgetown.edu/facpub

Part of the Administrative Law Commons, Antitrust and Trade Regulation Commons, International Law Commons, and the Law and Economics Commons 


\section{GEORGETOWN LAW Faculty Publications}

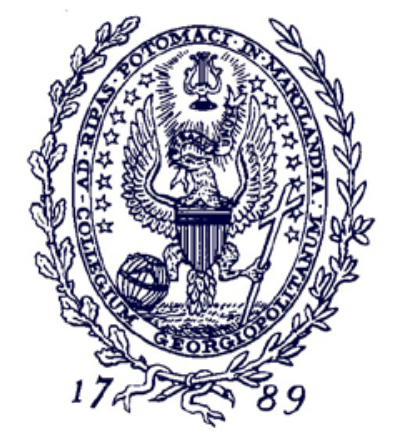

July 2010

\section{Global Governance: The World Trade Organization's Contribution}

46 Alta. L. Rev. 1061-1080 (2008-2009)

\author{
Andrew Mitchell \\ Visiting Associate Professor of Law \\ Georgetown University Law Center \\ am377@law.georgetown.edu
}

\author{
Elizabeth Sheargold \\ Researcher, Melbourne Law School \\ Researcher, Melbourne Law \\ $\underline{\text { sea } a, \text { unimelb.edu.au }}$
}

This paper can be downloaded without charge from:

Scholarly Commons: http://scholarship.law.georgetown.edu/facpub/386/

SSRN: $\underline{\text { http: / / ssrn.com/abstract }=1477544}$

Posted with permission of the author 


\title{
GLOBAL GOVERNANCE: THE WORLD TRADE ORgANIZATION'S CONTRIBUTION
}

\author{
ANDREW D. MitCHELL ${ }^{*}$ AND ELIZABETH SHEARGOLD ${ }^{* *}$
}

\begin{abstract}
Democracy and administrative law concern ideas of governance, legitimacy, and accountability. With the growth of bureaucracy and regulation, many democratic theorists would argue that administrative law mechanisms are essential to achieving democratic objectives. This article considers the World Trade Organization's (WTO) contribution to governance both in terms of global administrative law and democracy. In relation to administrative law, it first explores the extent to which the WTO's own dispute settlement process contributes to this area. Second, it considers the operation of administrative law principles embedded within the WTO Agreements on Members. For example, the WTO Agreements require that certain laws be administered "in a uniform, impartial and reasonable manner." This obligation was recently considered by the Appellate Body, but uncertainty remains about the scope this provision has to permit WTO panels to review domestic administrative practices. In relation to the WTO's contribution to democracy, this article first considers the challenges and limitations of the current system of decision making within the WTO and compares it to democratic theory. Second, it examines how democracies comply with the findings of WTO dispute settlement tribunals and how compliance could be improved. It concludes by speculating on the implications of this discussion for public international law more broadly.
\end{abstract}

La démocratie et le droit administratif concernent des idées de gouvernance, de légitimité et de responsabilité. Compte tenu de la croissance de la bureaucratie et de la réglementation, de nombreux théoriciens de la démocratie feraient valoir que les mécanismes du droit administratif sont essentiels pour réaliser les objectifs démocratiques. Cet article examine la contribution de l'Organisation mondiale du commerce $(O M C)$ à la gouvernance à la fois en termes de droit administratif et de démocratie à l'échelle mondiale. Par rapport au droit administratif, les auteurs explorent d'abord la mesure dans laquelle la méthode de règlement de conflit propre à l'OMC y contribue. Ensuite, ils examinent le fonctionnement des principes du droit administratif ancrés dans l'Accord instituant l'organisation mondiale du commerce. Par exemple, l'Accord exige que certaines lois soient appliquées " de manière uniforme, impartiale et raisonnable ». Dernièrement, cette obligation a été examinée par l'Organe d'appel, mais il y a encore de l'incertitude quant à la mesure dans laquelle cette disposition permet aux groupes d'experts de l'OMC de revoir les pratiques administratives intérieures d'un pays. En ce qui concerne la contribution de l'OMC à la démocratie, les auteurs examinent d'abord les défis et les limitations du système actuel de prise de décision au sein de l'OMC et le comparent à la théorie démocratique. Puis, ils examinent de quelle manière les démocraties respectent les conclusions des tribunaux de règlement de conflits de l'OMC et de quelle manière il serait possible d'améliorer la conformité. Les auteurs concluent en réfléchissant aux implications de cette discussion sur le droit public international au sens plus large.

\section{TABLE OF CONTENTS}

I. INTRODUCTION: GLOBAL GOVERNANCE AND THE WTO $\ldots \ldots \ldots \ldots \ldots$

II. The WTO AND Global Administrative LAW $\ldots \ldots \ldots \ldots \ldots \ldots$

A. Global Administrative LaW $\ldots \ldots \ldots \ldots \ldots \ldots \ldots \ldots$

* $\quad$ Ph.D. (Camb.), LL.M. (Harv.), Grad. Dip. (Int. Law) (Melb.), LL.B. (Hons.) (Melb.), B.Comm. (Hons.) (Melb.); Senior Lecturer, Faculty of Law, University of Melbourne; Barrister and Solicitor, Supreme Court of Victoria and High Court of Australia; Fellow, Tim Fischer Centre for Global Trade \& Finance, Bond University.

** LL.B. (Hons.) (Melb.), B.A. (Melb.); Researcher, Melbourne Law School, University of Melbourne. The authors would like to thank the participants at the Four Societies Special Colloquium in Canada in September 2008, as well as Simon Pitt and Tania Voon for their helpful comments and suggestions. 

B. ADMINISTRATIVE LAW PRINCIPLES
WITHIN WTO DiSPUTE SETTLEMENT $\ldots \ldots \ldots \ldots \ldots \ldots \ldots \ldots$
C. THE IMPACT OF GLOBAL AdMinistrative LaW

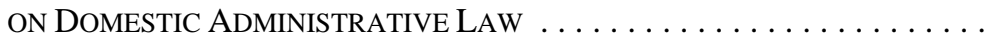
D. CASE STUdy: THE APPELLATE BODY REPORT

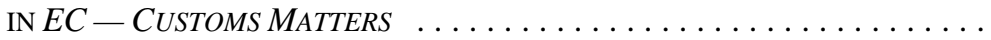

III. THE WTO's CONTRIBUTION TO DEMOCRACY $\ldots \ldots \ldots \ldots \ldots \ldots \ldots$

A. Decision-Making In THE WTO $\ldots \ldots \ldots \ldots \ldots \ldots \ldots \ldots \ldots$

B. DEMOCRACIES AND COMPLIANCE WITH

WTO DisPUTE SETTLEMENT $\ldots \ldots \ldots \ldots \ldots \ldots \ldots \ldots \ldots \ldots \ldots$

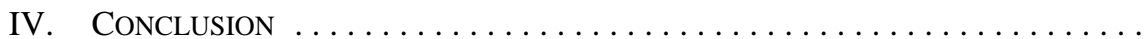

\section{INTRODUCTION: GLOBAL GOVERNANCE AND THE WTO}

Global governance has traditionally focused on the management of public international affairs through formal and informal interactions between states. Over the course of the last century, however, the globalization of an increasing number of socio-economic and environmental problems and improvements in technology have blurred the boundaries between public and private, and domestic and international. The focus of global governance has broadened significantly to include more diverse actors, institutions, networks, regimes, and mechanisms that exercise regulatory or distributive functions having transnational impacts. Thus, James Rosenau argues that global governance now "encompasses the activities of governments, but it also includes the many other channels through which 'commands' flow in the form of goals framed, directives issued, and policies pursued," where such exercises of control have transnational repercussions. ${ }^{1}$

The World Trade Organization (WTO) has evolved parallel to these fundamental shifts in how global governance is ordered. Although the WTO is an intergovernmental organization that is ultimately responsible to, and in many respects regularly influenced by, its members, it is appropriate to consider the role of the WTO in light of this more complex understanding of global governance. For instance, decision-making, administration, enforcement, and management tasks within the WTO are undertaken by a range of state and non-state actors using a variety of different mechanisms, many of which do not conform to more traditional understandings of governance, domestic or international.

In line with the increasing importance and complexity of global governance mechanisms, there has been significant controversy regarding the extent to which global governance is 
legitimate and accountable. ${ }^{2}$ The WTO has often been at the heart of these legitimacy and accountability debates. ${ }^{3}$

Two growing bodies of scholarly literature have emerged focusing on enhancing global governance. The first of these examines how global governance is improved through the adoption of administrative law-type mechanisms. ${ }^{4}$ The second focuses on analyzing and identifying ways of managing democratic deficits. ${ }^{5}$ This article aims to contribute to these two bodies of literature by identifying and analyzing a number of WTO activities, rules, and processes that have played a role in the development of global governance in this way.

To this end, Part II of this article assesses the WTO's contribution to global administrative law, both in terms of rules that apply internally to its dispute settlement process and those that have been imposed externally on members. Part III then considers the extent to which the WTO has added to our understanding how democracy should be conceptualized at a global level, with reference to both the decision-making processes in place in the WTO and the WTO's adjudication of disputes.

\section{The WTO AND Global Administrative LAW}

\section{A. Global Administrative LAW}

Global governance, like domestic governance, necessarily involves regulatory and administrative decision-making. "Global administrative law” refers to the rules, procedures, and systematized norms that control this decision-making, particularly mechanisms that promote principles such as accountability, transparency, and legitimacy. ${ }^{6}$ As foreshadowed above, global regulatory practices are blurring the traditional bright line distinctions between public/private, and national/international bodies, underpinned and supported by a perceptible shift towards a disaggregated system of governance rather than bounded government. ${ }^{7}$ "Bounded government” in a Lockean sense refers to government limited by laws in contrast

2 See e.g. Philip Alston, “The Myopia of the Handmaidens: International Lawyers and Globalization” (1997) 8 E.J.I.L. 435; John Glenn, "Global Governance and the Democratic Deficit: Stifling the Voice of the South” (2008) 29 Third World Quarterly 217; Sebastian Mallaby, "Big Nongovernment" Washington Post (30 November 1999) A29; Phillip R. Trimble, "Globalization, International Institutions, and the Erosion of National Sovereignty and Democracy” (1997) 95 Mich. L. Rev. 1944. See e.g. B.S. Chimni, "The World Trade Organization, Democracy and Development: A View From the South” (2006) 40 J. World Trade 5; Ralph Nader, “WTO Means Rule by Unaccountable Tribunals” Wall Street Journal (17 August 1994) A12; cf. “Who Elected the WTO?” The Economist 360:8241 (29 September 2001) 26; James Bacchus, "A Few Thoughts on Legitimacy, Democracy, and the WTO” (2004) 7 J. Int'l Econ. L. 667.

4 See e.g. Benedict Kingsbury, Nico Krisch \& Richard B. Stewart, "The Emergence of Global Administrative Law” (2005) 68:3 Law \& Contemp. Probs. 15.

5 See e.g. Alois Stutzer \& Bruno S. Frey, “Making International Organizations More Democratic” (2005) 1 Review of Law and Economics 305.

$6 \quad$ Kingsbury, Krisch \& Stewart, supra note 4 at 28.

$7 \quad$ Anne-Marie Slaughter, A New World Order (Princeton: Princeton University Press, 2004) at 12; Alfred C. Aman, Jr., "The Limits of Globalization and the Future of Administrative Law: From Government to Governance” (2001) 8 Ind. J. Global Legal Stud. 379; Martin Shapiro, "Administrative Law Unbounded: Reflections on Government and Governance” (2001) 8 Ind. J. Global Legal Stud. 369. 
to "absolutism." ${ }^{8}$ However, here we use "bounded government" to refer to the idea of a clear separation between, on the one hand, government and administration, and on the other, citizens and the administered. ${ }^{9}$ The clear delinations envisaged by this concept of bounded government have been challenged by the increasing involvement of non-governmental organizations, interest groups, private sector experts, "epistemic communities," and "networks" in administrative decision-making. This, in turn, demands that classical notions of accountability, democratic legitimacy, and legality of administrative decision-making be reconceptualized at both a practical and theoretical level in order to operate globally. This reconceptualization is necessary to the extent that these classical notions have been developed under a very different model of administration; one that focuses on the regulatory activities of "bounded" public government agencies operating within a single unified nationstate. Such a reconceptualization is made all the more necessary since, as has already been suggested, regulatory actors such as the WTO are increasingly encountering questions and concerns as to their legitimacy and accountability. ${ }^{10}$ These concerns pose a critical threat to the efficacy and democratic validity of the WTO and other transnational regulatory actors.

To combat this “democracy deficit," administrative law-type mechanisms, procedures, rules, and principles have begun to emerge, or have been purposefully woven into the fabric of a variety of bodies, both formal and informal, in the global administrative space. ${ }^{11}$ These developments form the foundation of "global administrative law." Despite not being presently systemically understood and somewhat fragmented as a body of law, some have suggested that core principles are emerging within global administrative law. ${ }^{12}$ These include a mixture of both classical administrative law conceptions of fair and legal decision-making and review procedures, and also more substantive, albeit nebulous, "public law" or "good governance" values. ${ }^{13}$ Together these principles include: procedural participation and transparency; reasoned decisions; access to review mechanisms; proportionality and reasonableness; avoidance of unnecessarily restrictive means; and legitimate expectations. ${ }^{14}$ This is not suggested as an exhaustive list, but rather a set of potential candidates for general principles ${ }^{15}$ as reflected in the practice of a presently disjointed, but nevertheless growing body of administrative law-type mechanisms.

The fact that these principles are linked to a transnational model of global governance rather than domestic government distinguishes them conceptually from their equivalents in the administrative and constitutional jurisprudence of domestic legal systems. ${ }^{16}$ The

Ian Harris, "Locke's Political Theory" in Stuart Brown, ed., British Philosophy and the Age of Enlightenment (London: Routledge, 1996) 96 at 99.

9

10

11

See Shapiro, supra note 7 at 369.

See generally Stutzer \& Frey, supra note 5.

See generally, Benedict Kingsbury, "The Administrative Law Frontier in Global Governance” (2005) 99 American Society of International Law Proceedings 143.

See Eleanor Kinney, "The Emerging Field of International Administrative Law: Its Content and Potential” (2002) 54 Admin. L. Rev. 415 at 416-17; Kingsbury, Krisch \& Stewart, supra note 4 at 15. For a detailed analysis of the distinction between prototypical administrative law procedural requirements and general public law values see Carol Harlow, "Global Administrative Law: The Quest for Principles and Values” (2006) 17 E.J.I.L. 187 at 194.

Kingsbury, Krisch \& Stewart, supra note 4 at 29.

Ibid. at 37.

Harlow, supra note 13 at 208. 
interrelationship of these principles to a transnational model of global governance is also reflected in how these principles are implemented and realized in the practice of global administration. The field of global governance is populated by a disparate collection of regulatory entities amongst which the task of global regulation and administrative decisionmaking is spread. In addition to this, the global administrative space has been said to be characterized by a disaggregation of nation-states into collections of sub-state regulatory actors that are increasingly networking across jurisdictions and national boundaries, ${ }^{17}$ forming a complex web of vertical and horizontal networks that are functioning alongside more traditional treaty-based international organizations.

An example of a horizontal network of regulatory actors is the Basel Committee on Banking Supervision. This committee comprises the representatives of the central banks (or other authorities with the formal responsibility of prudential supervision over the banking business) of 13 countries. Its objective is to improve understanding of supervisory issues and improve the quality of banking supervision. Examples of vertical networks are rarer, since they presuppose that states have chosen to delegate a limited amount of their sovereignty to a supranational institution. ${ }^{18}$ The clearest example of this occurring can be found in the European Union (EU), where vertical networks can be seen in the interaction between the European Court of Justice (ECJ) and the domestic courts of EU Members. ${ }^{19}$ This "disaggregated world order" ${ }^{20}$ is a complex system of administrative regulation quite far removed from classic domestic administration. A traditional understanding of administrative law focused on national government agencies operating as domestic "organs of public administration" 21 subordinated to legislative and judicial oversight within the unified framework of a nation-state and domestic legal order cannot be directly transplanted to the global or transnational context.

Against this background, it is not surprising that the task of providing a conceptual framework to underpin global administrative law, is as yet, incomplete. In the absence of such a framework, a functional definition of global administrative law may be posited as a placeholder. "Global administrative law" is all the rules, procedures, and systematized norms governing international regulation and administrative decision-making with special emphasis placed on the mechanisms that impose accountability, transparency, and legal legitimacy on global administrative decision-making. ${ }^{22}$ This classification not only covers the range of specialized mechanisms developed for specific international organizations and other transnational regulators, but also captures the ways in which domestic institutions and domestic administrative law may operate as a check on or a forum for review of decisionmaking by these organs of global governance.

The most important growth area for global administrative law in relation to these global regimes is likely to be the creation of specialized administrative law-type mechanisms

See Slaughter, supra note 7 at 12.

Ibid. at 13 .

Ibid. at 14.

Ibid. at 15 .

This is the traditional account referred to in Shapiro, supra note 7 at 369 .

Kingsbury, Krisch \& Stewart, supra note 4 at 28. 
operating at the global level and directed towards improving the transparency, opportunities for public participation, accountability, and thereby legitimacy, of transnational regulatory decision-making. Global administrative law ought to be, and has been, developed so as to provide the necessary checks and balances on transnational regulatory actors such as the WTO. This helps to ensure accountability, legitimacy, and the promotion of a sense of democratic participation and transparency in the development of global norms and regulations.

This article will consider the simultaneous "top down" and "bottom up" administrative law-type practices that are developing in the WTO and the contribution that they make. Richard Stewart categorizes "top down" administrative law mechanisms as those that originate in the international institution itself, while "bottom up" measures are those that stem from the domestic administrative law systems of the institution's members. ${ }^{23}$ First, we examine how the incorporation of administrative law principles in WTO Agreements has impacted upon domestic administrative procedures. Second, we turn to the incorporation of administrative law principles, such as due process, in WTO Agreements and the impact that this has on administrative procedures within the WTO, particularly in dispute settlement. Third, we examine the possibility for WTO dispute settlement to be considered as an extra layer of judicial review of domestic administrative decision-making.

\section{B. Administrative Law Principles Within WTO Dispute Settlement}

As discussed above, global administrative law, like domestic administrative law, goes beyond administrative mechanisms and rules, and includes principles such as due process, fairness, procedural participation, and transparency. The WTO contributes to the development of many of these principles at the global level as they are often included in the provisions of the WTO Agreements, such as the Understanding on Rules and Proceudres Governing the Settlement of Disputes. ${ }^{24}$ Fairness is reflected in many articles of the DSU, including the requirements regarding panel procedures ${ }^{25}$ and the granting of participatory rights to third parties in disputes. ${ }^{26}$ Thus, the implementation and interpretation of the WTO Agreements, such as these DSU provisions, adds to the development of global administrative law principles (that is, principles that can be applied to international regulatory and administrative decision-making).

One of the clearest examples of this is the development of the principle of due process (also called fundamental fairness, procedural fairness, or natural justice), which essentially requires administrative and judicial proceedings to be fair. Due process is a relevant principle in both domestic and global administrative law, as it is a necessary component of any legal system seeking legitimacy and effectiveness. ${ }^{27}$ Due process has been incorporated into the WTO dispute settlement system through both a “top down” and a “bottom up” approach, and

23 Richard B. Stewart, “U.S. Administrative Law: A Model for Global Administrative Law?” (2005) 68:3 Law \& Contemp. Probs. 63 at 71-72.

15 April 1994, 1869 U.N.T.S. 401 (entered into force 1 January 1995) [DSU].

See especially ibid., art. 12.

Ibid., art. 10.

Thomas M. Franck, Fairness in International Law and Institutions (Oxford: Clarendon Press, 1995) at 7-8. 
we will consider each of these in turn as a case study of how the WTO dispute settlement process is contributing to the development of global administrative law.

The WTO Appellate Body has said that the "procedural rules of WTO dispute settlement are designed to promote ... the fair, prompt and effective resolution of trade disputes." ${ }^{28}$ The $D S U$ incorporates the principle of due process in a range of ways, ${ }^{29}$ such as imposing a form of the bias rule. This rule precludes decision-makers from acting where there is a reasonable apprehension by others that they may be biased, for example because they have an interest in the outcome. ${ }^{30}$ For panels, the $D S U$ requires that panellists be free of any actual or perceived bias. Article 8(2) of the DSU states that panellists should be selected with a view to ensuring their independence, and art. 8(3) states that citizens of members involved in the dispute (as parties or third parties) should not serve as panellists unless the parties agree otherwise. Article 8(9) states that "[p]anelists shall serve in their individual capacities” and that members shall "not give them instructions nor seek to influence them as individuals with regard to matters before a panel." 31 The explicit inclusion of these due process rules in the $D S U$ provides a model upon which other international institutions can base dispute settlement systems.

This does not mean, however, that due process has been incorporated into the DSU in exactly the same form, or to exactly the same extent as it exists in many domestic contexts. There are some $D S U$ provisions that appear to undermine transparency and due process, ${ }^{32}$ such as the confidentiality of panel deliberations and Appellate Body proceedings ${ }^{33}$ and the confidentiality of submissions. ${ }^{34}$ These provisions deliberately prioritize the rights of disputants over the rights of third parties, NGOs, corporations, and non-WTO members. This reflects a desire by the treaty drafters to make the WTO a member-driven organization, with its primary duty being the protection of its members' interests through mechanisms such as state-to-state dispute settlement. However, certain WTO members have recently been successful in opening up WTO dispute settlement proceedings to the public. Members such as the United States and the European Communities (EC) provide copies of their submissions on government websites, ${ }^{35}$ while Canada makes their submissions available upon request. ${ }^{36}$

United States - Tax Treatment for "Foreign Sales Corporations" (Complaint by the European Communities) (2000), WTO Doc. WT/DS108/AB/R at para. 166 (Appellate Body Report).

See generally Andrew Mitchell, "Due Process in WTO Disputes” in Rufus Yerxa \& Bruce Wilson, eds., Key Issues in WTO Dispute Settlement (New York: Cambridge University Press, 2005) 144.

Peter E. Nygh \& Peter Butt, eds., Australian Legal Dictionary (Sydney: Butterworths, 1997) s.v. "bias rule."

DSU, supra note 24, art. 8(9).

Bryan Mercurio \& Rebecca Laforgia, "Expanding Democracy: Why Australia Should Negotiate for Open and Transparent Dispute Settlement in its Free Trade Agreements” (2005) 6 Melbourne J. Int'l L. 485 at $492-93$.

DSU, supra note 24, arts. 14(1), 17(10).

Ibid., art. 18(2).

See online: Office of the United States Trade Representative <http://www.ustr.gov/Trade_Agreements/ Monitoring_Enforcement/Dispute_Settlement/WTO/Section_Index.html>; online: European Commission <http://ec. europa.eu/trade/issues/respectrules/dispute/index_en.htm>; WorldTradeLaw.net provides links to other governments that make WTO dispute settlement submissions available, online: WorldTradeLaw.net <http://www.world tradelaw.net/submissions.htm>.

See online: Foreign Affairs and International Trade Canada <http://www.international.gc.ca/tradeagreements-accords-commerciaux/disp-diff/index.aspx?lang=en>. 
These members have also requested on certain occasions that both panel and Appellate Body hearings be opened to the public through closed circuit television broadcast. The first such hearings to be made public were part of the $E C$ - Hormones dispute, when, in 2005, the EC challenged both the U.S. and Canada's continued suspension of concessions. ${ }^{37}$ In July 2008 , the Appellate Body hearing on the same matters was also made open to public viewing. ${ }^{38}$ While the $D S U$ provisions state that panel deliberations and Appellate Body proceedings are to be confidential, in the EC - Hormones dispute, the Chairman of the Panels stated that after careful consideration of the existing provisions of the $D S U$, there was nothing prohibiting proceedings from being made public where the parties consented, while third parties who did not want their submissions to be public could participate in a closed hearing of the panel or Appellate Body. ${ }^{39}$ Thus, WTO members have been able to strengthen due process in WTO dispute settlement, with a "view to ensuring full transparency and non-discriminatory access" to hearings. ${ }^{40}$ While not all WTO dispute settlement proceedings are now open to the public, the opening of even a few cases sets a valuable precedent for dispute settlement in other forums, such as bilateral and multilateral free trade agreements or customs unions. ${ }^{41}$

The incorporation of the principle of due process into WTO Agreements contributes to the development of global administrative law through both "top down" and "bottom up" approaches. Its inclusion in the $D S U$ provides a model for how due process can be incorporated into the rules of other dispute settlement systems, and reflects a "top down" approach where the administrative law principles were imposed by the institution itself. In contrast, the shift towards making some WTO dispute settlement proceedings open to the public demonstrates a "bottom up" approach, where the administrative law principles (such as transparency) that stem from members' domestic legal systems have been be used to influence an international institution - even when that institution initially adopted practices that were directly contrary to these principles.

\section{THE IMPACT OF GLOBAL AdMinistrative LAW ON DOMESTIC ADMinisTrative LAW}

While global administrative law is clearly shaped and influenced by domestic administrative law, as it develops, this relationship will become increasingly reciprocal with global administrative law requirements and norms having a greater impact on domestic administrative systems. Several of the WTO Agreements also impose an obligation on WTO members to afford due process within their domestic legal systems. This raises the possibility of a significant challenge for global administrative law, namely the potential for conflicts to arise when domestic and global administrative law impose conflicting procedural

United States - Continued Suspension of Obligations in the EC - Hormones Dispute, Canada Continued Suspension of Obligations in the EC — Hormones Dispute (2005), WTO Docs. WT/DS320/8, WT/DS321/8 (Communication from the Chairman of the Panels) [EC - Hormones].

38 See WTO Dispute Settlement News, online: WTO <http://www.wto.org/english/tratop_e/dispu_e/ public_hearing_july08_e.htm>. Subsequent Appellate Body hearings are also being opened to the public, e.g. EC - Bananas (Article 21.5) held in October 2008, online: WTO <http://www.wto.org/ english/news_e/news08_e/hearing_22sept08_e.htm>.

39. EC-Hormones, supra note 37.

$40 \quad$ Ibid.

$41 \quad$ Mercurio \& Laforgia, supra note 32 at 514. 
requirements or substantive principles. The imposition of obligations on members need not involve direct prescription of administrative procedures for domestic legal systems by the WTO Agreements; it is enough for a broad due process requirement to exist at the global level alone where its satisfaction imposes domestic obligations. For example, in a decision considering a U.S. import restriction on shrimp and certain shrimp-related products, ${ }^{42}$ the WTO Appellate Body found that the application of the ban denied affected countries due process $^{43}$ and, consequently, the ban could not be justified under the chapeau requirements found in art. XX of the General Agreement on Tariffs and Trade. ${ }^{44}$ In order to be exempt from the U.S. import ban, countries needed to have their imports "certified" as meeting certain environmental standards imposed by the U.S. on its own shrimp trawlers. However, the Appellate Body found that this certification process did not comply with the fundamental requirements of due process and involved "arbitrary or unjustifiable discrimination” within the meaning of the chapeau of art. $\mathrm{XX} .^{45}$

While the Appellate Body did not prescribe the specific administrative procedures that had to be implemented by the U.S. in order for the requirements under the chapeau of art. XX to be met, it did highlight the absence of certain procedures as indicating a lack of due process:

[T] here is no formal opportunity for an applicant country to be heard, or to respond to any arguments that may be made against it, in the course of the certification process before a decision to grant or to deny certification is made. Moreover, no formal written, reasoned decision, whether of acceptance or rejection, is rendered on applications.... No procedure for review of, or appeal from, a denial of an application is provided. $^{46}$

In response to this finding, the U.S. redesigned its measure to be more flexible, for example by providing that a "country that does not appear to qualify for certification will receive a notification that 'will explain the reasons for this preliminary assessment, suggest steps that the government of the harvesting nation can take in order to receive a certification, and invite the government of the harvesting nation to provide ... any further information." " 47 As a consequence of its international law obligations to the WTO, the U.S. domestic administrative procedure needed to be adjusted so as to provide the requisite degree of procedural fairness to foreign states and affected producers. ${ }^{48}$ Despite the lack of a direct effect of WTO law on U.S. law, its domestic administrative procedures were substantively altered as a consequence of a WTO ruling. This provides a clear example of how administrative law requirements being introduced at a global level can have significant implications for domestic administrative law.

United States - Import Prohibition of Certain Shrimp and Shrimp Products (Complaint by Pakistan) (1998), WTO Doc. WT/DS58/AB/R (Appellate Body Report) [US - Shrimp].

Kingsbury, Krisch \& Stewart, supra note 4 at 36.

30 October 1947, 55 U.N.T.S. 187 (entered into force 1 January 1948) [GATT]; for more detailed discussion of the US - Shrimp decision, and its connection with "due process" as a principle of WTO law, see Andrew D. Mitchell, Legal Principles in WTO Disputes (New York: Cambridge University Press, 2008) at 173-75.

US - Shrimp, supra note 42 at para. 186.

Ibid. at para. 180.

United States - Import Prohibition of Certain Shrimp and Shrimp Products (Recourse to Article 21.5 of the DSU by Malaysia) (2001), WTO Doc. WT/DS58/AB/RW at para. 147 (Appellate Body Report). Kingsbury, Krisch \& Stewart, supra note 4 at 36. 


\section{Case Study: The Appellate Body Report in EC - Customs MatTers}

The broad scope of the potential impact that global administrative law could have in domestic law can be seen in the report of the Appellate Body in European Communities Selected Customs Matters. ${ }^{49}$ The GATT requires that domestic laws relating to customs and valuation of goods be administered in a "uniform, impartial and reasonable manner." 50 This provision goes beyond merely incorporating an administrative law principle into the WTO Agreements; instead, it creates the potential for WTO panels to review a member's domestic administrative practices. This is also seen in art. $\mathrm{X}(3)(\mathrm{b})$, which states that each WTO member shall maintain or create "judicial, arbitral or administrative tribunals or procedures for the purpose, inter alia, of the prompt review and correction of administrative action relating to customs matters." ${ }^{\text {"1 }}$ Both of these provisions were considered by the Appellate Body in the EC - Customs Matters dispute. Although the Appellate Body report left uncertainty regarding the scope of review of a WTO member's domestic administrative practices, it made some important contributions to the development of administrative law in the WTO, and hence to global administrative law as a whole.

The Appellate Body addressed a large number of procedural issues of WTO law in this case, ${ }^{52}$ but also some key substantive aspects of the GATT, art. X(3). ${ }^{53}$ Three of the Appellate Body's findings are particularly relevant to the development of global administrative law: first, whether the substantive content of an administrative legal instrument may be challenged as a form of administration; second whether art. X(3)(a) requires uniformity of administrative processes leading to a particular decision; and third, its determination on the requirements of art. X(3)(b).

\section{Can a Substantive Instrument Be Within the Meaning of “ADMINISTER” FOR THE PURPOSES OF ARTICLE X(3)(a)?}

The EC argued in EC - Customs Matters that laws and regulations themselves cannot be challenged under art. X(3)(a) of the GATT and instead that only the administration of those laws or regulations can be reviewed by a WTO panel..$^{54}$ In earlier cases the Appellate Body had emphasized that the requirement to be "uniform, impartial and reasonable" 55 applied only to the administration of laws and regulations, and not to the "substantive content" of the

(2006), WTO Doc. WT/DS315/AB/R (Appellate Body Report) [EC - Customs Matters, Appellate Body].

GATT, supra note 44, art. X(3)(a).

Ibid., art. X(3)(b).

Procedural issues including the U.S. drafting of its request for the establishment of a panel, the terms of reference issued, and what precisely was the "measure at issue." On the "measure at issue," see generally Alan Yanovich \& Tania Voon, "What is the Measure at Issue?” in Andrew D. Mitchell, ed., Challenges and Prospects for the WTO (London: Cameron May, 2005) 115.

For a discussion of the procedural aspects and the background to the dispute, see: Davide Rovetta \& Michael Lux, "The US Challenge to the EC Customs Union" (2007) 2 Global Trade and Customs Journal 195.

EC - Customs Matters, Appellate Body, supra note 49 at para. 48.

GATT, supra note 44, art. X(3)(a). 
instruments themselves. ${ }^{56}$ Agreeing with the arguments of the EC, the Panel in EC Customs Matters held that the U.S. was unable to challenge EC regulations under art. $\mathrm{X}(3)(\mathrm{a})$, and instead could challenge only the administration of those regulations. ${ }^{57}$ However, on appeal, the U.S. successfully argued that, broadly speaking, there are two different categories of laws and regulations - those that are "administrative in nature," which can be challenged in general under art. X(3)(a), and those that are not, which can be challenged under art. X(3)(a) only with respect to their administration. ${ }^{58}$ The Appellate Body reasoned that the text of art. X(3)(a) and its earlier decisions on the interpretation of that provision do not exclude the possibility that a legal instrument regulating the administration of customs laws can be challenged. ${ }^{59}$ In order to make out a claim of this kind, the burden was held to lie with the complainant to demonstrate that the instrument "necessarily leads to a lack of uniform, impartial, or reasonable administration." ${ }^{60}$ In EC - Customs Matters, although the Appellate Body found that the different penalty laws and audit procedures in place in the EC were administrative measures, it considered that the U.S. had failed to discharge this burden of proof. ${ }^{61}$

This Appellate Body finding raises important considerations for WTO members. While the due process obligations under art. X(3)(a) may not seem to be an onerous requirement, these sorts of administrative law principles are necessarily vague and difficult to define. Moreover, it is a standard that numerous WTO members have not met in the past. By deciding that this requirement can apply to laws and regulations that are administrative in nature, the Appellate Body has embraced a broad interpretation of art. X(3)(a), meaning that this requirement will apply to a greater range of domestic measures adopted or maintained by WTO members. Thus, the Appellate Body's decision in EC - Customs Matters demonstrates the potential for international institutions to broadly interpret their power to evaluate the adequacy of a member's domestic administrative law systems.

\section{ARE DifFERENCES in AdMinistrative Process CoMMENSURATE WITH DIFFERENCES IN ADMINISTRATION?}

In spite of this broadening of the scope of art. $\mathrm{X}(3)(\mathrm{a})$, difficulties remain in the interpretation of the requirements it imposes. This can be seen in the Appellate Body's assessment of whether the "uniformity" requirement extends to administrative processes. The Panel had held that the difference between the administrative process leading to the tariff classification of blackout drapery lining in Germany and other EC members constituted non-

Eropean Communities - Regime for the Importation, Sale and Distribution of Bananas (Complain by Ecuador et al.) (1997), WTO Doc. WT/DS27/AB/R at paras. 199-204 (Appellate Body Report); European Communites - Measures Affecting the Importation of Certain Poultry Products (Complaint by Brazil) (1998), WTO Doc. WT/DS69/AB/R at para. 115 (Appellate Body Report). European Communities - Selected Customs Matters (Complaint by the United States) (2006), WTO Doc. WT/DS315/R at paras. 7.114-7.119 (Panel Report) [EC - Customs Matters, Panel]. EC - Customs Matters, Appellate Body, supra note 49 at paras. 25-31; see also Argentina - Measures Affecting the Export of Bovine Hides and the Import of Finished Leather (Complaint by the European Communities) (2000), WTO Doc. WT/DS155/R at paras. 11.69-11.72 (Panel Report). EC - Customs Matters, Appellate Body, ibid. at para. 200.

Ibid. at para. 201.

Ibid. at paras. 210-14, 216. 
uniform administration contrary to art. X(3)(a). ${ }^{62}$ However, the Appellate Body held that art. $\mathrm{X}(3)$ (a) does not require that uniform administrative processes be adopted throughout the territory of a member. Rather, it is the actual application of the law that must be uniform. ${ }^{63}$ The Appellate Body also noted that differences in administrative process can still constitute evidence that the processes are applied in a manner that is not "uniform, impartial or reasonable," with the burden resting on the complainant to prove that the varied processes lead or are likely to lead to administration of the law that is not uniform, impartial and reasonable. ${ }^{64}$ The Appellate Body reversed the Panel's finding of a violation in connection with the tariff classification of the drapery lining on the basis that this burden had not been met.

The conclusion that art. $\mathrm{X}(3)$ (a) does not require uniformity of administrative processes, however, sits uncomfortably with the Appellate Body's construction of the term "administer" as including administrative processes. ${ }^{65}$ On this interpretation of administration, it would seem that differences in administrative processes must logically constitute differences in administration. Nonetheless, the Appellate Body reasoned that administrative processes potentially cover such a broad range of "steps, actions, or events" that art. X(3)(a) could not be read as requiring them to be uniform. ${ }^{66}$ More problematic however, is that the Appellate Body does not clearly explain the threshold differences in process that must be demonstrated before they will be deemed to "have caused" or be "likely to cause" ${ }^{\text {"67 }}$ non-uniformity of administration. That this issue was not addressed in the Appellate Body's report appears to reflect the difficulty of applying administrative principles to WTO members, particularly in the case of the EC where WTO obligations are ultimately executed by subsidiary, national bodies.

\section{WHAT ARE THE REQUIREMENTS OF ARTICLE X(3)(b)?}

The third particularly notable aspect of the Appellate Body decision in EC - Customs Matters relates to the U.S. claim under art. $\mathrm{X}(3)(\mathrm{b})$ of the GATT. The administrative decisions of EC customs officials are reviewed at first instance under the domestic administrative law of the relevant EC member (a system of territorially restricted judicial review), and the resulting decisions have binding or precedential value only within the territory of that EC member. The U.S. claimed that this system of territorially restricted judicial review violates the requirements of art. $\mathrm{X}(3)(\mathrm{b})$, arguing that the use of the term "the agencies entrusted with administrative enforcement" ${ }^{\prime \prime 8}$ in the plural indicates that the decisions of a member's judicial, arbitral, and administrative tribunals must govern the practice of all agencies responsible for enforcing the relevant laws. The Appellate Body rejected this claim, finding that there were a number of possible explanations for the reference to "agencies" in the plural in the provision. Further, they held that the use of the terms "tribunals" and "procedures" in the plural in fact indicates that WTO members may

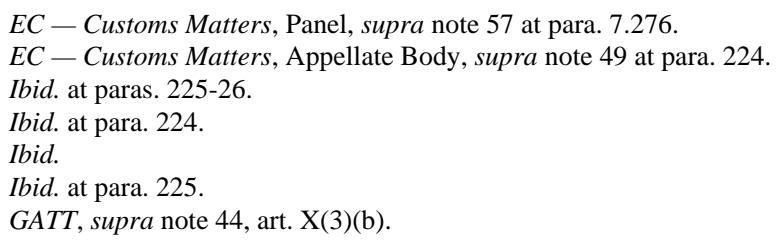


establish a number of tribunals within their territory having different substantive or geographic areas of competence. ${ }^{69}$ Of itself, this finding may not have particular significance for the development of global administrative law as it focuses on the interpretation of the terms in art. X(3)(b). However, it clearly demonstrates that WTO panels and the Appellate Body are prepared to adjudicate on whether or not domestic administrative procedures meet the requirements of art. X(3)(b). While they took an approach in EC-Customs Matters that was quite deferential to the domestic systems operating in the EC, future adjudications concerning this provision could have a very significant impact on global administrative law.

In a disaggregated world order, intergovernmental organizations and government networks are relying on domestic agencies, which typically boast superior coercive power, to administer an increasing number of international rules. ${ }^{70}$ Accordingly, future cases concerning this provision - for example, a challenge that a member's domestic administrative review mechanisms do not meet the art. X(3)(b) requirement of independence - provide enormous and significant potential for the development of global administrative law, as judicial review is a powerful check on administrative power. The potential impact of this provision and its interpretation in the global administrative space is particularly significant for members where the independence of judicial review has been a significant concern. $^{71}$

Part II of this article has addressed the WTO's contribution to the development of global administrative law. Yet the development of global administrative rules, principles, and systemized norms is not a goal in itself; it is a means of ensuring accountability, transparency, and legitimacy. It is these broader goals of good governance that global administrative law seeks to further. The next section of this article examines the role of the WTO in contributing to the development of notions of "democracy” and good governance in the international sphere.

\section{THE WTO’s CONTRIBUTION TO DEMOCRACY}

In order to assess the WTO's contribution to how democracy can be conceptualized and implemented at the global level, we first need to consider the key elements of democratic theory, particularly as they relate to global governance and international institutions. A range of principles are associated with democratic systems of government, such as participation, transparency, accountability, majority rule, liberty, representation, equality, and the rule of law. These core characteristics of modern "liberal” democracies can be considered key tenets of democratic theory that are applicable at both the domestic and international levels. The most central feature of any democracy is that "government should be by the citizenry" and with their consent, even if this, for practical reasons, mostly occurs through a system of representative government. ${ }^{72}$ Democratic systems derive their very legitimacy from the fact

\footnotetext{
$69 \quad$ EC - Customs Matters, Appellate Body, supra note 49 at paras. 297-304.

$70 \quad$ Slaughter, supra note 7 at 11.

71 Consider the case of the People's Republic of China, where judicial review continues to be subjected to interference by the Communist Party: see e.g. Veron Mei-Ying Hung, “China’s WTO Commitment on Independent Judicial Review: Impact on Legal and Political Reform” (2004) 52 Am. J. Comp. L. 77.

72 Craig Forcese, "Hegemonic Federalism: The Democratic Implications of the UN Security Council's 'Legislative’ Phase” (2007) 38 V.U.W.L.R. 175 at 176.
} 
that they have the consent of the governed. Further, while in a representative democratic system the majority rules, there also cannot be a tyranny of the majority - there must be respect for rights, equality, and an effective rule of law. It is frequently argued that these principles - government by consent and the rule of the majority being tempered by rights, equality, and the effective rule of law - are lacking in global governance mechanisms, and subsequently that there is a "crisis of democracy" at the international level. ${ }^{73}$

One of the most often repeated criticisms of international institutions and laws is that they lack democratic legitimacy because government is not being conducted by the citizenry. ${ }^{74}$ In particular, compared to domestic democratic systems, at the international/global level, there are "democratic deficits." "75 The concept of a "democratic deficit" is that an institution or government that is ostensibly democratic is falling short of fulfilling key principles of democracy. ${ }^{76}$ Most commonly in international law, the term is used when an organization is believed to not adequately represent or reflect the will of its citizens. International institutions such as the WTO are generally based on the principle of sovereign equality, with membership open only to states. Assuming that all states act in the interests of the majority of their population, this system is still seen to exclude minority groups within states and NGOs from these institutions, but is also criticized as it denies individual people the direct ability to consent (or not consent) to the laws and policies developed by these institutions. Moreover, many smaller or less powerful states may not consent to the formation of laws that bind them (or consent because of diplomatic or political pressures), or do not participate in the processes that develop international norms or customs.

Whether the WTO undermines or supports democratic principles is a contested topic. The current Director-General of the WTO, Pascal Lamy, has given a series of speeches promoting the organization's contribution to the development of global governance. ${ }^{77}$ Lamy argues that the WTO, while not providing a perfect model, is playing a significant role in this area. The WTO, he observes, provides a permanent forum for negotiations by member states and conducts annual public fora and regular briefings for non-state parties. It also monitors member behaviour through peer review programmes such as the WTO Trade Policy Review Mechanism. Finally, he notes that the WTO provides a mechanism for adjudicating and enforcing members' rights and obligations. In contrast, a range of NGOs and other

73 Jan Aart Scholte, “Civil Society and Democracy in Global Governance” (2002) 8 Global Governance 281 at 289. See also Steve Charnovitz, "The Emergence of Democratic Participation in Global Governance (Paris, 1919)” (2003) 10:1 Ind. J. Global Legal Stud. 45.

74 For a detailed discussion of different democratic theories and international law, see Gerry J. Simpson, "Imagined Consent: Democratic Liberalism in International Legal Theory” (1994) 15 Australian Yearbook of International Law 103.

75 José E. Alvarez, “Introducing the Themes” (2007) 38 V.U.W.L.R. 159 at 159.

76 See Sanford Levinson, "How the United States Constitution Contributes to the Democratic Deficit in America” (2007) 55 Drake L. Rev. 859 at 860.

77 See e.g. Pascal Lamy, “Towards Global Governance?” (Master of Public Affairs Inaugural Lecture at the Institut d' Etudes Politiques de Paris, 21 October 2005), online: WTO <http://www.wto.org/english/ news_e/sppl_e/sppl12_e.htm>; Pascal Lamy, “The World Trade Organization: A Laboratory for Global Governance” (Malcolm Wiener Lecture at the John F. Kennedy School of Government, Harvard University, 1 November 2006), online: WTO <http:/www.wto.org/english/news_e/sppl_e/sppl47_e. htm>. 
commentators argue that the WTO is fundamentally undermining democracy. ${ }^{78}$ This article undertakes an objective examination of the contribution of the WTO to democracy at the global level by first considering how decision-making in the WTO both embodies and diverges from democratic theory. It will then go on to discuss the enforcement of WTO dispute settlement decisions in democratic states, and how this affects democratic principles in those states.

\section{A. DECISION-MAKING IN THE WTO}

The system of decision-making used in the negotiation of rules and treaties within the WTO has two key features. First, decisions are made by the members, who are almost entirely states, ${ }^{79}$ on the basis of one nation, one vote. This principle of sovereign equality is the basis for most (but not all) classical international institutions. The second feature is unique to the WTO - that is the use of consensus as the basis for all major decision-making. This was the practice under the GATT, and was included in art. IX(1) of the Marrakesh Agreement Establishing the World Trade Organization. ${ }^{80}$ Both of these features are significant in terms of democratic theory. We will address each feature in turn.

As outlined above, in order for a state to be considered democratic it must represent the will of its citizenry. At the international level, the issue is, of course, who are the "citizens" of global organizations? While states may be the formal members of the WTO, it is now widely argued that the citizens of an international organization's member states are also the citizens of the organization. ${ }^{81}$ Thus, the ability of these individuals to participate in WTO decision-making, including through civil society organizations such as NGOs or through corporations, is a key element in its contribution to democracy. The fact that these citizens have no legal right to participate in the negotiation of WTO Agreements is clearly a concern in terms of the democratic legitimacy of the WTO. Lamy argues that there is an increasing role for private actors within the WTO through the dispute settlement process, particularly when compared to the mechanisms in other international institutions. ${ }^{82}$ WTO panels and the Appellate Body have the discretion, although they are not obliged, to accept amicus curiae briefs from non-state actors. They have done so on many occasions, ${ }^{83}$ and as was discussed above, there has been a recent trend towards opening panel and Appellate Body hearings to the public. ${ }^{84}$ The first public hearing of the Appellate Body occurred in July 2008 in the EC - Hormones dispute, where the disputing parties (the EC, U.S., and Canada) requested that the hearing be open to the public (although some third parties' submissions were not able to be viewed by the public, at the request of those parties). ${ }^{85}$ While this new openness and transparency in dispute settlement sets positive and important precedents for global

See e.g. online: Third World Network <http://www.twnside.org.sg/>; see also online: World Development Movement <http://www.wdm.org.uk>.

Of course, the WTO also allows customs territories, such as the EC, to be members.

15 April 1994, 1867 U.N.T.S. 154 (entered into force 1 January 1995) [Marrakesh Agreement].

See Saskia Sassen, “The Participation of States and Citizens in Global Governance” (2003) 10:1 Ind.

J. Global Legal Stud. 5.

Lamy, “Towards Global Governance?,” supra note 77.

US - Shrimp, supra note 42.

See supra note 38 and accompanying text.

Ibid. 
governance, it is still a long way from ensuring avenues for non-state actors to participate in and scrutinize all WTO decision-making.

Democratic theory, when applied to international institutions, assumes that private actors, such as individuals or corporations, are able to be involved in decision-making processes through their national governments. Yet there is no guarantee that this will occur. For example, there is no requirement of procedural fairness or due process imposed by the WTO on the involvement of national officials in transnational regulatory negotiations, such as the regular and often ongoing negotiations that take place within the WTO. ${ }^{86}$ Domestic laws determine the requirements that a national official is subject to when negotiating on behalf of their country. While the failure of a national official to adequately consult with their relevant domestic constituents is a failing of national democracy, it also affects the democratic legitimacy of the transnational regulations. If the representatives of each state are not adequately representing their citizens, then the end result of those negotiations will likewise not adequately represent the needs and wants of those citizens. In many circumstances, national laws do not require that the state's representatives at international negotiations act with procedural fairness. For example, in the U.S., a non-profit public interest organization ${ }^{87}$ unsuccessfully sought a declaration from the Court of Appeal (District of Colombia Circuit) that the United States Trade Representative (USTR) was under an obligation to prepare an environmental impact statement addressing international trade agreements under negotiation. ${ }^{88}$ The need for the preparation of such a statement for public consultation and procedural fairness was subsequently acknowledged by Executive Order 13,141, under which the President mandated that an environmental review be conducted and related in both draft form enabling public comment, and in final form. ${ }^{89}$ This represents the imposition of administrative law-type procedures on the participation of the USTR in global negotiations, but only in one case with no guarantee that future negotiators will be subject to the same procedures. ${ }^{90}$ Generalizing the requirement that negotiators are subject to the obligations of procedural fairness would create a situation in which citizens in each of the states represented in negotiations would enjoy a degree of de facto participation in the decision-making process. The degree of such participation would depend on the extent that citizens could effectively influence the negotiating position of their respective representative through domestic mechanisms for political accountability. However, despite the desirability of such an approach, at present it is limited to a collection of isolated examples. ${ }^{91}$

The principle of sovereign equality has another shortcoming in terms of democratic theory. It presumes that all states have an equal ability to negotiate and bargain in international negotiations. Article XVI(5) of the Marrakesh Agreement prevents members from making any reservations from the WTO Agreements, except as expressly permitted in

\footnotetext{
$86 \quad$ Stewart, supra note 23 at 88.

87 The organization was Public Citizen, online: Public Citizen <http://www.citizen.org/>.

88 Public Citizen v. Office of the United States Trade Representatives, 970 F.2d 916 (D.C. Cir. 1992).

$89 \quad$ U.S. Exec. Order No. 13,141, 3 C.F.R. 235 (1999), s. 5.

90 However, interestingly the Executive Order, ibid., s. 7, explicitly states that it does not create any procedural responsibility enforceable at law, thereby apparently precluding future judicial challenge grounded in a failure to carry out this procedural requirement.

$91 \quad$ Kingsbury, Krisch \& Stewart, supra note 4 at 33.
} 
those Agreements, thereby establishing the "single-undertaking." 92 The result of this is that if a country wishes to gain any of the benefits of WTO membership, they must accept all of the obligations that come along with that. While this may not sound problematic, it must be considered that the WTO Agreements cover an incredibly broad range of subject matter, such as phytosanitary regulations, intellectual property laws, technical standards and regulations, and customs procedures. Given the huge economic importance of gaining WTO membership for many developing countries and Least Developed Countries (LDCs), often these nations will accept undesired conditions of membership that they would not accept if they had more equal bargaining power or the ability to make reservations. Thus, the single-undertaking principle, along with the process of negotiated accession to the WTO, establishes a system where states with little bargaining power have a limited ability to consent to various terms or agreements. Again, this raises significant questions about the operation of democratic principles in the WTO. ${ }^{93}$

However, even if it is accepted that all WTO members fully consent to all elements of each WTO Agreement, this still has implications in terms of democratic deficit. The principle of consensus that underpins negotiated decision-making in the WTO is intended to remove many of these concerns about states being bound by laws or rules that they did not consent to. The principle of consensus is perhaps the ultimate means of preventing the tyranny of the majority, as any single state has the theoretical ability to stop an agreement being formed. But this of course has very serious implications for the efficacy of WTO negotiations and decision-making. This also has negative implications for democracy. The inability of the WTO to adopt policies that the majority of members may support, such as agricultural liberalization, means that the majority cannot prevail, and instead a minority viewpoint "rules.” Moreover, Lamy himself admits that this system of consensus makes the WTO institutionally weak, ${ }^{94}$ and this weakness undermines the "efficiency" of the WTO, a characteristic that he argues is needed in any model of “"good' global governance." 95

\section{B. DEMOCRACIES AND COMPLIANCE WITH WTO DISPUTE SETTLEMENT}

\section{Does Compliance With WTO Dispute SETTLEMENT Within DemOCRATIC NATIONS UNDERMINE DEMOCRATIC WiLL Within ThOSE NATIONS?}

In relation to decision-making, this article has considered whether mechanisms within the WTO are consistent with democratic theory. Yet this is not the only way in which the WTO interacts with democratic theory. Compliance with decisions of the WTO dispute settlement system can impact upon the domestic democratic systems of members. What does a member do when a decision of the Dispute Settlement Body (DSB) requires them to act in a way that violates their domestic democratic legal system or principles? Furthermore, do democratic systems within some member states, in turn, undermine the dispute settlement system of the WTO?

\footnotetext{
$92 \quad$ Marrakesh Agreement, supra note 80, art. XVI(5).

93 On the significance of consent by states in international democratic systems, see Simpson, supra note 74.

$94 \quad$ Pascal Lamy, “Towards Global Governance?,” supra note 77.

95 Pascal Lamy, “The World Trade Organization: A Laboratory for Global Governance,” supra note 77.
} 
For the majority of WTO members, WTO law and decisions of the DSB do not have direct legal effect. In other words, they must be implemented by the domestic government. Thus, the WTO does not have the power to compel private entities within a state to act, yet often compliance with the WTO Agreements has a direct impact on these private actors. One of the clearest examples of this is in relation to cases where it is found that a subsidy has been or is being provided by a member in violation of the Agreement on Subsidies and Countervailing Measures. ${ }^{96}$ In the Brazil - Export Programme for Aircraft dispute, the Appellate Body held that domestic law and contractual obligations cannot be used to justify the failure to withdraw an export subsidy. ${ }^{97}$ Similarly, in the Australia - Subsidies Provided to Producers and Exporters of Automotive Leather dispute, the Compliance Panel held that a non-recurring subsidy that had been provided to a private company had to be repaid in full to the Australian government, even though no domestic legal basis existed to compel the company to repay the subsidy as under domestic law the subsidy had been legally granted..$^{98}$ Thus, compliance with WTO dispute settlement decisions may require violations of domestic law and legal principles. Moreover, even where compliance does not involve infringement of the legal rights of private parties, any shift in national policy in a democratic state that is compelled by an external body, such as the WTO, challenges the democratic foundations of that state. However, assuming that the decision to accede to the WTO was initially made by democratically elected representatives, complying with an unpopular WTO ruling is not necessarily undemocratic. Rather, members are simply being held to follow rules that their governments agreed to uphold. Further, members could always leave the WTO if their citizens formed the view that the costs of adverse rulings outweighed the benefits of membership.

\section{Does Popular Will Within Democratic Nations Undermine COMPLIANCE WITH WTO DisPuTE SETTLEMENT, AND HENCE THE EFFECTIVENESS OF GLOBAL GOVERNANCE?}

The preceding section assumed that democratic states always comply with the recommendations and rulings of the WTO DSB. ${ }^{99}$ But, as has just been mentioned, often the will of the people (or the will of significant political actors) within these states may go against these recommendations and rulings. In this way, democratic will at the national level can work to undermine the effectiveness of international law. As noted above, it is a general precept of international law that domestic law cannot be used as an excuse for failure to meet international obligations. Within the WTO, the DSU requires that all members comply with rulings made against them, regardless of their domestic obligations. This could be seen to contribute to the development of global governance by putting international law on a level that transcends national concerns and political considerations.

15 April 1994, 1869 U.N.T.S. 14 (entered into force 1 January 1995).

Brazil - Export Financing Programme for Aircraft (Complaint by Canada) (2000), WTO Doc. WT/DS46/AB/RW at paras. 46-48 (Appellate Body Report).

Australia - Subsidies Provided to Producers and Exporters of Automotive Leather (Recourse to Article 21.5 of the DSU by the United States) (2000), WTO Doc. WT/DS126/RW at para. 6.39 (Panel Report). Bruce Wilson, "Compliance by WTO Members with Adverse WTO Dispute Settlement Rulings: The Record to Date” (2007) 10 J. Int’l Econ. L. 397 (noting the generally high level of compliance). 
Within the WTO, a party that wins a dispute may retaliate under art. 22 of the $D S U$ if the losing party does not bring their measure into compliance with the relevant WTO Agreement within a reasonable period of time. However, in some circumstances, the threat of retaliation or cross-retaliation is simply not enough to induce compliance. This has been the case most notably in disputes concerning two of the most significant (and democratic) WTO members - the U.S. and the EC. In the EC - Hormones dispute, the Appellate Body report finding that the EC measure was in violation of the WTO Agreements was adopted by the DSB in February 1998. Yet it was not until November 2003 that the EC notified the DSB that it had altered its measure to comply with the Appellate Body decision and, even then, its attempt to comply with the report is currently being challenged by the U.S. and Canada. Similarly, in the European Communites - Regime for the Importation, Sale and Distribution of Bananas dispute, the initial request for consultations was made on 5 February 1996, and the Appellate Body report was circulated on 9 September $1997 .{ }^{100}$ Yet since that date, the EC has still failed to comply with the rulings of the Appellate Body concerning the import of bananas and preferences given to the African, Caribbean, and Pacific (ACP) countries.

In each of these cases, there are powerful and long-standing political views within the EC that supported the inconsistent measures. Consumer and environmental lobby group pressure was a significant reason for the ongoing ban on hormone-treated meat being sold in Europe. The lobby groups launched extensive anti-hormone-treated meat media campaigns, which helped to create a strong public sentiment in favour of hormone free products. ${ }^{101}$ When the European Commission suggested that it might lift the ban on a small range of hormones in 1995, the European Parliament (where consumer and environmental lobby groups enjoy considerable influence) strongly resisted this move, and ultimately the Commission backed down. ${ }^{102}$ Many of these same consumer groups support the continued blanket ban on hormone-treated meat in the EU, even though such a ban has been found to be inconsistent with WTO obligations. ${ }^{103}$

These cases demonstrate that while the $D S U$, in theory, forces members to comply with its rulings regardless of their domestic considerations and obligations, in practice this has not always been effective. This of course does mean that the WTO has been a failure in this regard. These examples are the exception, not the rule. The experience of the WTO, where generally members do comply with dispute settlement rulings, makes an important contribution to global governance by demonstrating how systems can be set up to induce compliance with international rules and obligations. However, these exceptional cases also demonstrate that the WTO system is not perfect, and that perhaps stronger enforcement mechanisms need to be considered. It is therefore not only true that global governance may at times undermine democracy; democracy may also undermine global governance. by Ecuador et al.) (1997), WTO Doc. WT/DS27/AB/R (Appellate Body Report). Harvard University Press, 1995) at 156-57.

103 See e.g. The European Consumers' Organisation (BEUC), online: BEUC < $<$ ttp://www.beuc.eu/Content/ Default.asp>; Trans Atlantic Consumer Dialogue (TACD), online: TACD <http://www.tacd.org/cgibin/db.cgi?page=view\&config=admin/press.cfg\&id=43> . 


\section{CONCLUSION}

Contrary to popular perceptions, the WTO has clearly made an important contribution to global governance, although it is more understated and nuanced than some of its proponents might suggest. While the WTO does incorporate administrative law principles both within its own dispute settlement system and, to a more limited degree, by imposing them on its members, the application of these principles is subject to significant constraints. Decisionmaking is broadly democratic, but particular WTO rules, processes, and decision-making structures could be considered undemocratic in that they affect, and in some cases override, the domestic administrative decision-making processes of members. In other words, a tension exists between the WTO's substantive contributions to global governance through its regulatory functions, and the impact of such contributions on democracy and procedural justice - themselves important aspects of global governance. 